\title{
202. 口蓋扁桃におけるランゲルハンス細胞の局在と同定
}

\author{
免疫電子顕微鏡にて— \\ 中村晴彦 (蒲郡市民) 西村忠郎・八木沢幹夫 - 鈴木昭男 - 岸本 厚 - 竹内健二 \\ 森島夏樹（保衛大第 2）
}

目的 ランゲルハンス細胞㹥1868年 P. Langerhans によりヒト表皮内に樹枝状突起を有する細胞として発 見された，微細構造上細胞質内にバーベック顆粒と呼 ばれる構造物を有する細胞で，表皮，真皮，リンパ節， 胸腺，食道など重屬局平上皮や扁平上皮化生する粘膜 上皮内に存在して㧍り，T-cell 系列に抗原情報を提供 する機能を有している。今回我々は，S-100 $\alpha^{-} \beta^{+}$蛋白 抗体（日本抗体研究所）を用い，醳素抗体法を施行， 倒立法にて epon 包埋し詳細な免疫電子顕微鏡的観察 を行い，口蓋扁桃の陰简上皮内にバーベック顆粒を有 するランゲルハンス細胞の存在を確諗できた。

方法 口蓋扁桃摘出術を行った扁桃組織 22 例を用い た. (1) 摘出後ただちにPLP 固定にて前固定を行い, 10\%，20\% Sucrose 加 PBS 液にて置換. (2) Compound 包埋を行い, 液体サッソによる凍結後, クリ才 スタットにて 4 6 $6 \mathrm{~mm}$ に薄切. (3) $0.3 \% \mathrm{H}_{2} \mathrm{O}_{2}$ メ夕夕 一ル液にて内因性ペルオキシダーゼ除去し, $\mathrm{ABC}$ 法に て醅素抗体法を施行. (4) $\mathrm{DAB}-\mathrm{H}_{2} \mathrm{O}_{2}$ 中で発色させた。 同一 2 標本作製のうち，一方はメチルグリーンにて核 染を行い, 光学顛微鏡にて観察。もう一方の標本は,
$1 \%$ $\%$ オウにて後固定. アルコール脱水後エポン 包埋し, 超薄後, 透過型電子顕微鏡にて観察した, 一 次抗体には，パパイン分解を行い分子量を低下させ， 細胞膜を通過できるようにした S-100 $\alpha^{-} \beta^{+}$蛋白抗体 を用いた。

結果 i ）上ト口葢扁桃陰墖上皮内に，バーベック 顆粒を有するランゲルハンス細胞が認められた。 ii) ランゲルハンス細胞は，比較的円型でクロマチンに富 さ核が存在していた。細胞質は樹枝状形をしており， 細胞質内には大，小顆粒球が豊富に認められた。しか し，粗面小胞体はあまり発達していなかった。 iii）パ パイン分解した S $-100 \alpha^{-} \beta^{+}$蛋白抗体は, ランゲルハ ンス細胞の細胞膜を透過し，細胞質内にある顆粒球を 染色した。したがってこの抗体は，ランゲルハンス細 胞の同定に有用ですると思われた。貿問 菊池恭 三(日大)，1）病巣感染の疾患㤌何か．2）標本の大き さで成績は異なるか。，答 1) 掌蹠膿疱症 4 例， 腎炎 2 例の計 6 例を用いた，2）写真上の問題だけて， 形態的には変化は認められない。

\section{3，組織培養法を用いた扁桃組織内における 貪食細胞及び免疫担当細胞の検討}

\author{
鳥越達也・漆畑 保・石倉幹雄・竹山 勇 (聖マリアンナ大)
}

目的我々はこれまでに濾胞樹状細胞を中心とした 屏桃組織内の主に非リンパ球系細胞につき，その凍結 切片を用いて免疫組織学的に検討してきた。雟桃組織 内においては，滤胞樹状細胞が以前は貪食能を有した 細胞であったものが，その㗢きを失ったものとして肧 中心の骨格を形成しているとの考え方があるが，いま だ確立されていない，そこで，今回は各種細胞の同定 のためにHRPと組織培養を用いた免疫組織学的染色 を行い, 濾胞樹状細胞の暑食能の有無交検討し, 同時 にこれまで我々が 2 次元的組織標本をもとに行ってき た扁桃実質組織内における貫食能を持つ細胞の分布に ついて塗林標本を用いて検討した。

万法 検体は手術的に摘出した10代から20代の習慣

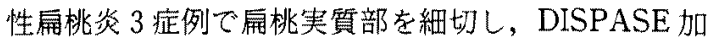
Eagle's MEN 内にて濃度が一定の純胞浮遊夜を作成 しスライドに塗抹したものに，各種モノクロナール抗 体を用い，ABC 法にて染色し陽性細胞数を測定した。 今回使用したモノクロナール抗体は抗 DRC-1抗体及 び抗 Macrophage 抗体の 2 種類であり,さらに貪食能
を有する細胞の検討には HRP加 Eagle's MEM 中に て一片 $3 \mathrm{~mm}$ 角の痌桃実質部を37度で 1 時間培盖し， その後凍結標本を作り, 免疫組織学的二重染色を行っ た。

結果 (1) 外因性の異物であるHRP 取り込んだ 貪食細胞は扁桃実質内へ遊走し，しかも既に存在して いる脴中心内へも一部入りこんでいた（2）DRC-1抗 体とHRPとの2 重染色標本より濾胞樹状細胞と HRP 隄性細胞が同一の胚中心内に存在し，しかも，そ れが同一の細胞であるものはなく，マクロファージが 濾胞樹状細胞へ変化するという考光は否定的と思力れ た.(3) 鋰抹標本による扁桃実質内における滤胞樹状細 胞とマクロファージの細胞比率は，(A) 滤胞樹状細胞： $2.53 \pm 0.99 \%$ (B) マクロファージ: $3.67 \pm 1.68 \%$ で つた。質問 中村晴彦(保衛大第 2 ). 染色標本が 凍結により堙れて，細胞質が外部に流出しているよう に見えるが，いかがか. 応答 抗 DRC-1 は細胞膜 に抗原性をもつものであり, antolysisの評価は難し い。ただ培虽標本は，染色性が低下しており，抗原性 
が低下していることは考えられる。質間 草刚 潤(東北大). DRC-1 陽性細胞とマクロファージ陽性細 胞の染色性がちがうからといって，樹状細胞がマクロ ファージ由来ではないと言えるのか. 応答今回 は $\mathrm{M} \phi$-DRC のみではなく, HRP 貪食細胞-DRC-1の
2 重染色より検討した，會食細胞 $(\mathrm{M} \phi)$ からFDC 人 変化するならば, 同一の細胞ないしは, 両細胞の移行 期にある細胞の存在が考えられるが，今回はそのよう な細胞が見られなかった。

\section{IgA 腎症症例における扁桃の免疫組織学的検討}

\section{草刈千賀志・高坂知節（東北大）}

はじめに IgA 腎症は原発性糸球体腎炎の一つで, 口蓋扁桃摘出により，その臨床症状の軽減・軽快をみ る症例が多く，最近扁桃病兽感染症として注目を集め ている，我々は，IgA 腎症症例及び通常の慢性崙桃炎 症例両群の摘出扁桃に対して, IgA の陽性細胞数なら びに局在をサブクラス別に免疫組織学的に比較検討し た。

万法 対象は憼生検にて $\operatorname{IgA}$ 腎症と診断された症 例 8 例, および通常の慢性府桃炎症例 8 例でる。外 科的に摘出された口蓋扁桃をPLP-micro wave 固定 後倲結包埋, クリオスタットにて薄切し, 抗 IgA1, 抗 IgA2 抗体 (Becton-Dickinson) を用いたABC 法を行 い, DABにて発色した。

結果 i) 俩桃に㧍いては，両群ともIgA1 陽性細 胞が IgA2 陽性細胞に比し優位であった，ii） IgA1 陽 性細胞数はIgA 腎症群において増加していた， iii） IgA 腎症群では IgA1 が follicular dendritic cell (FDC)に陽性であったが，慢性扁桃炎群においては陰 性であった。

考察 IgA 腎症において系球体メサンギウム領域に
能勢真人・京極方久 (同・第一病理)

沈着しているのは IgA1であるといわれている.今回, IgA 腎症群の扁桃においてのみFDCに IgA1 が陽性 を示したことは，IgA 㷂症と扁桃のかかわりを示唆す る所見として興味深いものであった.FDCには免疫複 合体 (IC) を細胞内に保有する性質があると同時に抗 原提示能を有する。扁桃の FDCに存在する IgA1 は， 流血中より移行したか，または扁桃内にて形成された IgA-ICであると考えられ，IgA 筒症の発症進展にお ける归桃の免疫学的役割を理解する上ての重要な手が かりとなると思われる。筫問 川上晋一郎(岡山 大). 扁桃と腎の $\operatorname{IgA}$ 陽性率との相関はどうであった か. 応答 腎組織との検討は行わなかった。質 問 形浦昭克(札医大)。発症機序に関して $\mathrm{T}$ cellの subclass， $\alpha, \delta$ 細胞について検討しているか. 応 答 $\alpha \delta$-cellも染めてみたが病桇瀜桃で特に違いはな かった。質問 鳥越達也(聖マリアンナ大).IgA 腎 症々例の扁桃組織て, 抗 DRC-1 抗体と抗 $\operatorname{lgA}-1$ 抗体 の染色性で胚中心毎に，染色性に差が見られたか。

応答 DRC-1 の局在を考えたうえで、す心て合理的な 分布であった。

\section{5.ラット鼻咽頭リンパ組織（NALT）の微細構造}

林 佐和子・山根辰生 ·東川俊彦 ·増田 游 (岡山大)

$$
\text { 菊田彰夫・大谷 修（岡山大第二解剖） }
$$

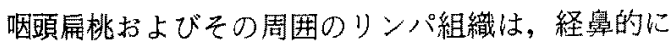
侵入する病原菌に対する防御機構として重要な役割を 担っている、ラットでは，咽頭と鼻腔の境界部にりン パ組織が存在し, nasal associated lymphoid tissue (NALT) と呼ばれている (Spit et al. 1989)。このう ットNALTの微紐構造わよび血管構築を調べた。

材料と方法 Wistar 系雄ラット（体重 $200 \mathrm{~g} \sim 300 \mathrm{~g}$ ) を用いた，通常の組織学的方法に従って光顕および電 䫓用試料を作製した。また，鋳型樹脂注入により，血 管鋳型を作製して，走查電顕にて血管網の観察を行っ た.

結果 NALTは, 両側鼻腔が合流して咽頭管に移行 する部分の, 左右両下外側壁に存在する. NALTは,

一層の上皮細胞に覆われ, germinal center と暗殼を有
するリンパ滤胞の集合体である。堛胞の辺縁部および 滤胞間域は多数の粘液細胞を含む多列円柱緎毛上皮で 覆われるが, 滤胞直上には，瀻毛を持たない細胞高の 低い上皮細胞が集合している部分が存在し，この部分 には，リンパ上皮共生が認められた。走查電影による 観察により，繊毛を持たない上皮細胞を，疎な微䋐毛 を持つもの，短微絨毛が密生したもの，表面が平滑な ものの三種類に分類できる. NALTには，蝶口蓋動脈 の枝が分布し，この動脈は，濾胞内および滤胞間域を 内腔に向かって上行しながら分枝を出して濾胞および 滤胞間域に毛細血管網を形成し，さらに上皮下では， 不規則に分枝吻合を繰り返す一層の毛細血管縂を形成 する。滤胞内，滤胞間域および上皮下毛細血管網は， 各領域で高内皮静脈に流入し, 高内皮静脈は濾胞を包 